piety cannot, as a general rule, be sincere."18..

Was the dinner with Simpson and his friends at 52 Queen Street a sober occasion? Physically speaking, perhaps; intellectually it could hardly be. How one would like to re-create the scene! Simpson in charge, large and amiable, spreading his girth and his presence around him; ${ }^{19}$ and Andersen the honoured guest, tall and thin, supported on his huge feet, dressed in an odd combination of wide trousers and high, starched collar; childlike and charming withal. Two minds of a totally different cast, but in harmony and alight.

\section{REFERENCES}

1 Obituary, Medical Times and Gazette, 1870, 1, 530.

2 Duns, J., Memoir of Sir fames Y. Simpson, Bart., p. 204. Edinburgh, Edmonton \& Douglas, 1873.

Siebold, E. von, Abhandlungen $K$. Gesellschaft für Wissenschaften, $1845-7,3,116-140$.

4 Siebold, E. von, Neue Zeitschrift für Gerburtskunde, 1848 onwards, passim.

5impson, Sir James Young, Notice of a new anaesthetic Agent, as a Substitute for sulphuric Ether in Surgery and Midwifery. Edinburgh, Sutherland \& Knox; London, S. Highley, 1847

"I am told that the London physicians, with two or three exceptions only, have never yet employed ether-inhalation in their Midwifery practice. Three weeks ago, I was informed in a letter from Professor Montgomery of Dublin, that he believed that in that city, up to that date, it had not been used in a single case of labour." Notice, p. 13.

7 This letter is published in J. Duns' Memoir of Sir fames Y. Simpson, Bart, p. 208. Edinburgh, Edmonton \& Douglas, 1873. Smith was the first person in England to use chloroform in midwifery, (see his "On the Use of Chloroform in Midwifery Practice," Lancet, 1847, 2, 572).

8 The best, indeed the only, account of this hospital is in W. R. Winterton's "The Story of the London gynaecological Hospitals," Proceedings of the Royal Society of Medicine, 1961, 54, 191. The author of this article quite rightly regrets the lack of recognition for Smith and his pioneer hospital. An interesting dispute in the affairs of the Hospital, in which Protheroe Smith clashed with the staff, is reported in the Medical Times and Gazette, 1874, 1, 374,
438, and in the British Medical fournal, 1874, 1, 284, 325, 330, $497,688,726$.

For information on Smith's inventive capacities and the trouble which these sometimes generated, consult the correspondence in the Lancet, $1850,1,706,723,761$. The subject is Smith's new the Lancectum.

9 Obituary, Lancet, 1889, 1, 770.

10 Snow, J., Lancet, 1847, 1, 228.

11 Latham, E., Medical Times and Gazette, 1847, 16, 96.

12 Smith, P., Lancet, 1847, 1, 452.

13 Gardner, J. (1804-80) translated and edited J. von Licbig's Familiar Letters on Chemistry, London, Taylor \& Walton, 1843-4, and was a prime figure in the founding of the Royal College of Chemistry in 1844. He wrote several times on ether, in particular an article entitled "On ether-vapour, its medical and surgical uses," Lancet, 1847, 1, $349,431$.

14 Osler, Sir W., Bibliotheca Osleriana, p. 149. Oxford, Clarendon Press, 1929.

15 Obituary, British Medical fournal, 1899, 1, 1311.

16 Munksgaard, E Ed. Hans Christian Andersen's Visits to Charles Dickens as described in his Letters. Copenhagen, Munksgaard, 1937.

17 Crawford, F., Ed. Hans Christian Andersen's Correspondence with the late Grand-Duke of Saxe-Weimar, Charles Dicken:, etc. the late Grand-Duke of

$18 \mathrm{I}$ am indebted for these bare details of Andersen's stay in Scotland to a short article by W. M. Parker contributed to the Evening Dispatch of 8 September 1943. ("The amiable Dane: Hans Andersen's Visit to Scotland".) This appears to be all that is written on the subject. It was discovered for me by Miss M. Deas of the National Library of Scotland. A readable biography of Andersen is S. Torvig's Life of Hans Christian Andersen published by Macmillan, London, in 1933.

19 Simpson's style at table was well calculated to thaw the chilliest of guests and to inspire camaraderie where none previously existed: "Lords and Commons rub shoulders at his table; the salt of the earth sit down side by side with the savourless; tweed jostles broadcloth; the town-bred Briton looks askance at his countrybred compatriot, and both unconsciously shudder at the Briton with bred compatriot, and both unconsciously shudder at the Briton with no breeding at all. In one room are assembled together the
American of bluest blood; the Yankee bagman; the slave-owning Southerner, and even the man of colour hateful to both alike. In a few minutes, under the genial influence of his presence, all tongues are set a-wagging". (see H. L. Gordon's Sir fames Young Simpson and Chloroform (1811-70), p. 82. London, T. Fisher Unwin, 1897.

\title{
The Eternal Triangle
}

\section{MARY POWELL,* S.R.N., M.C.S.P.}

\section{British Medical fournal, 1970, 2, 416-418}

I have been struck so often lately by the eagerness with which many of my nursing colleagues in hospital look forward to their retirement that I began to wonder why this is so. This eagerness to lay down arms seems to me to be a new development-it is not so long since I was listening to my seniors describing their dread of retirement and wondering how they would occupy their time. What forces have wrought such changes in senior nurses? Surely the very same ones which, directly or indirectly, create such havoc in the ranks of their juniors and which are demonstrated by high wastage rates and steadily diminishing numbers of new recruits. And these forces are fatigue, frustration, disappointment, disillusionment, and despair. Fatigue from long working hours combined with the frustration of knowing that patients are often inadequately cared for and student nurses inadequately taught; the disappointment and disillusionment which comes from lack of support from colleagues; and, finally, despair of finding a remedy for the ills which beset our profession at the present time.

We are agreed, I think, that our sorest and most serious affliction is, quite simply and in most situations, too much work for too few hands. Hard work well done is enjoyable if in the doing the patient receives the care he deserves and the student or pupil nurse the teaching she requires, but all too often these objectives are out of our reach because of chronic and insurmountable staff shortage.

* Matron, The Robert Jones \& Agnes Hunt Orthopaedic Hospital, Oswestry, Shropshire.

\section{Deterioration in Relationships}

But there is another reason for our despair, which, surprisingly enough, is never listed among the causes of dissatisfaction with nursing as a profession, and that is the change that has taken place in our relationships with doctors and with hospital administrators. This change is clearly demonstrated by the fact that the recent "Raise the Roof" campaign for improved salaries for nurses was very poorly supported by doctors, and by administrators not at all. The fact is that we no longer enjoy the support of our fellow workers in medicine and in administration, and all too often we get the impression that not only do they lack appreciation of our difficulties but they just do not want to know.

A consultant surgeon once told me he "couldn't understand this staff shortage" and that, moreover, he was "tired of hearing about it." But he will have to understand it, and he will have to hear about it, and, what is more, he will have to help us to do something about it if his patients are to receive adequate nursing care in the future. I have also been told, by an administrator, "I cannot pour any more money into nursing," yet what does pouring money into nursing represent if not adequate day-to-day care for the sick of this country?

What has happened to those vital relationships with doctors and administrators without which we ourselves cannot function either effectively or happily? It is as if our "marriage" had failed and mutual trust, mutual respect, and mutual confidence had flown out of the window. Unfortunately, as in all 
unhappy marriages, it is the children, in this case represented by our patients, who suffer from the effects of uneasy relationships between those responsible for their care.

Some doctors are totally unaware of the changes that have taken place in nursing; others are sceptical and even contemptuous of such innovations as the Salmon Committee proposals. Then some doctors and administrators "do not believe in higher education for nurses" and are scornful of the very idea of management training; the fact that nurses have "managed" since the days of Florence Nightingale seems to have escaped them.

It is interesting to note that the dilution of professional nursing by the introduction of the enrolled nurse, the nursing auxiliary, the ward orderly, and the ward clerk has not alleviated the staff shortage to any noticeable extent, nor has it brought true student status for nurses nearer to realization. One wonders how much the dilution of professional nursing by these additional grades has affected our relationship with doctors. Once upon a time a doctor was a doctor and a nurse was a nurse; nowadays a doctor is still a doctor, but a nurse may be anything from a "Salmon grade 10" to a nursing auxiliary.

It is most noticeable that the estrangement between doctor, administrator, and nurse is not present at clinical level and begins only when the nurse becomes involved in administration. All too often the first time a nurse dares (or, what is more significant, is driven) to take issue with a doctor or administrator is at ward sister level. How many nurses have had their first "disagreement" with a doctor on the age-old dispute regarding "extra beds"? What nurse questioned the efficiency of the administration of the ancillary services in hospital before she found herself "filling in" for clerk, domestic assistant, and porter? The nurse has been all things to all men for far too long; she has at last woken up to this fact, but can she awaken other sleepers?

\section{Responsibility and Status}

In the hospital service I think that the widest gulf which yawns between nurses on the one hand and doctors and administrators on the other is caused by the fact that only the former really know what it is to face, day in and day out, the hideous onus of maintaining a 24-hour service for 365 days and nights of every year. Unless actually experienced it is quite impossible to appreciate this responsibility, which has always fallen fairly and squarely (if fairly is the word) only upon nursing staff. Moreover, though there has been a tremendous proliferation of other grades of staff (particularly in the administrative and clerical grades) during the past two decades, these ancillary workers are conspicuous only by their absence in the evenings, at night, and at weekends.

The nurse may often be outnumbered by other workers from nine till five, Monday to Friday, but during other, unpopular, working hours she finds herself without domestic, portering, or clerical assistance. Not that I am suggesting that doctors do not work long hours, for of course they do, and I have known administrators to put in many extra sessions beyond the call of duty; but the fact remains that the nurse, and only the nurse, is required to provide a service which involves being with the patient continuously over the whole of the 24 hours. The anxiety of senior nurses who struggle to maintain this service by one means or another has to be experienced to be appreciated; I believe it to be one of the heaviest burdens carried by any worker in the hospital service.

Another very potent cause for resentment, particularly among senior nursing staff, is the fact that in some instances the lay administrator has apparently been raised to a status, real or imagined, where he is (or fondly imagines he is) "superior" to senior members of the nursing staff. For example, in one group known to me a hospital secretary is stated to have said that he has "five matrons working under him." The operative word is "under," and it is this word to which we must take exception. The attitude which I have just described is not to be tolerated, and senior administrators must take care to see that their juniors do not transgress in this connexion. Doctors are neither answerable to nor subservient to hospital administrators, so why should professional nurses be treated differently? The hospital administrator now wields tremendous power in the Health Service by virtue of the fact that he controls the purse strings, and we all know that money not only talks but often actually calls the tune.

Nurses now not only appear at times to be outnumbered by other workers but there is evidence to suggest that they may, in time and comparatively speaking, actually be outnumbered by doctors. In 1949 the number of nurses and midwives in relation to doctors in the Birmingham region was 9.2; in 1968 this figure had fallen to 8.8. I once heard a Chinese gentleman being asked his views on polygamy; his reply was, "Confucius says, one teapot can fill many cups"-similarly, one doctor can keep many nurses busy, but what happens when many more doctors keep fewer nurses busier still?

\section{Attitude towards Nurses}

The greatest tragedy of the present situation lies in the fact that nurses seem to be at cross purposes with doctors and administrators, who are in turn equally disenchanted with nurses. A consultant physician told me that for him "nurses had toppled off their pedestals," and a senior administrator said "nursing is just a job and nurses are just like everyone else now." The inference is that nurses were once regarded with respect and as rather "special" people but that this is no longer the case. The fact of the matter is that in the past the doctor and administrator looked on the nurse rather as a Victorian husband looked on his wife-as the little woman always at hand to minister to the needs of her lord and master. But the Victorian wife, and indeed the Victorian woman, has disappeared, and so has the Victorian nurse; present-day wives and women expect to be treated as equal partners in life's endeavours, and so do present-day nurses.

There is no doubi, however, that with emancipation the nurse has sacrificed the protective and fatherly attitudes once shown to her by doctors and administrators. In the past she may have been treated like a Victorian wife, but she also enjoyed the Victorian wife's security, and her status in relation to her professional colleagues was never in doubt. Today, for the first time since Florence Nightingale, she is struggling to maintain her place in the health team, and it is this factor which produces the conflict so much in evidence now.

\section{A Serious Imbalance}

The crux of the present situation lies in the fact that social changes beyond our control have resuited in a serious imbalance in the triangle represented by nursing, medicine, and lay administration, on which the care of the patient in hospital is inescapably based. We have all to some degree been overtaken by events, but the nursing side of the triangle has been affected to a greater and a more far-reaching extent than have the other two sides. It is as if the sides of the triangle represented by medicine and administration had grown in length and strength in comparison with the third, whose efforts to match its opposite numbers lead to constant strain, stress, and unhappiness for the people involved.

What can be done to rectify this imbalance, this malalignment, this uneasy situation, this disturbed relationship? The answer cannot lie wholly with the nurse, who represents the weakest side of the triangle, but with the two most powerful sides, represented by the doctors and administrators-and in particular with the doctors, because they are the leaders of the therapeutic team and because we look to them, as we 
have always done and will always do, not only to give orders for the care of our patients but to be a source of inspiration and strength.

Many thoughtful doctors and administrators deplore the sad deterioration of relationships between nurses and themselves and are very much aware of the extent to which they too are the losers; in the past nurses have offered to their professional colleagues infinite goodwill, respect, and loyalty-are these not worth preserving?

\section{Conclusion}

We must somehow convince our opposite numbers, both in medicine and in administration, that our side of the triangle must be recognized, must be honoured, must be regarded in every sense as of equal importance to the other two and as an equal partner in the care of the sick. Unless this is accomplished, and accomplished soon, the means by which our sick people are cared for is in jeopardy. The nurses of this country, for the first time in their history, have lately shown themselves to be militant in the matter of salaries; I am convinced that this demand for more money reflects a much deeper need-for true recognition as profes-

\section{ONE HUNDRED YEARS AGO}

\author{
Reports from Paris by a Special Correspondent: From the \\ British Medical Fournal, 14 May 1870
}

Professor Tardieu and the Students of Medicine.There was absolute quiet in the Amphitheatre this afternoon at Professor Tardieu's lecture: there has also been absolute quiet all day long in the streets of Paris; but in neither case has the outward calm resulted from inward contentment. The continuance of the precautionary measures, described in my last (p. 478), keep the turbulent students in check just as at the moment I write the strategic distribution of a vast army prevents the Parisian anti-Imperial majority of yesterday's plebiscite from re-enacting the old revolutionary Saturnalia of barricades and pillage.

I regret to say that the order and quiet in which Professor Tardieu is now permitted to lecture does not arise from his having enlisted the good feeling of the students who in a normal state of the School would constitute his regular audience. The numerous attendance and friendly reception of this day week, it now appears, were due in a great measure to the precautions adopted, and not-as I hoped when I wrote my last letter-to the re-establishment of a good understanding between professor and students.

This day week, there were rather more than 500 present; at the next lecture, on Wednesday, the auditory was only about 100. At the beginning and end of the lecture, the Professor was applauded. As on the opening day (Monday), the great iron gates were closed, and admission was only allowed by the Secretary's guichet and on presentation of tickets issued by the Dean. During the lecture, about 100 students collected in a group outside the gates, and 40 sergents-de-ville were posted on the Place de l'Ecole de Médecine to prevent any unruly proceedings. When Professor Tardieu left in his carriage, ten or twelve youths called out "A bas Tardieu! Vendu!" In a few minutes all was quiet. On Friday, the audience was scarcely 70 : the external manifestations were very similar to those of Wednesday. I make these statements on the authority of a gentleman who was there both days. Today, sional colleagues, for true participation in the management of our patient and his environment, and, as a natural corollary, for true professional satisfaction for ourselves. All the money in the world will not give us iob satisfaction, and only the concerted action of the other two sides of the triangle in which we work will save us from further and higher wastage from the profession, from lowered standards of patient care, from further impoverishment of recruitment, and finally, and most regrettable of all, from strike action in one form or another.

British nursing has always been regarded as the best in the world; never before in the history of this country have senior nurses experienced the deep unease and anxiety which exists today. We can only appeal to those to whom, after all, our work is as vital as it is to ourselves to listen to what we have to say before it is too late. On behalf of nurses I would like to appeal to doctors and administrators in words taken from Shakespeare's King Henry VIII :

"I will not wish you half my miseries, I have more charity, But say, I warned ye;

Take heed, for Heaven's sake, take heed, lest at once

The burden of my sorrows fall upon ye."

being present for a short time, I was able to observe for myself. When I arrived at a quarter-past four, there were no students outside the gates, nor were there any to be seen in the court within. Admission by the Secretary's guichet was alone allowed. I found Professor Tardieu lecturing to almost empty benches. The exact number present when I entered was 39. During the twenty minutes I remained, nine left the amphitheatre, and were replaced by about an equal number who probably came casually that they might see how matters were settling down. Deducting casual visitors, there were not, I fancy, present to-day more than 20 who could be regarded as regular students attending to benefit by the lectures. The students, in fact, have now adopted towards Professor Tardieu a policy precisely analogous to that adopted yesterday by one section of the Republican party, in the comices-the policy of "abstention"-neither saying "oui" nor "non" to the plebiscite formula of the Emperor. The students are evidently continuing their opposition; they have only changed the form; for active riot and outrage they have substituted the passive manifestation of a conspicuous absence. As there is no compulsory attendance on any of the classes in the Medical School of Paris, this sulky passive form of opposition may be indefinitely prolonged. The friends of a "free" system of medical teaching desire to keep the breach open. Le Soir of Saturday says: "We are assured that the fourth year students have determined that silence shall reign around Professor Tardieu, and with that object have resolved not to attend his lectures."

"Free Medical Teaching" Movement.-Large meetingsconvened by private circulars - have been held at 108 rue Bonaparte (Salle Pascaud) in connection with this movement. The meetings took place at 8 o'clock P.M. on the 29th April and 5th May. On both occasions M. Martin, a student of medicine, did the honours. The discussions may lead to some changes. 